\title{
Modern environmental problems of the Kyzylorda region: challenges and possible solutions
}

\author{
Turgai Alimbaev ${ }^{1}$, Zhanna Mazhitova ${ }^{2, *}$, Assemgul Bogenbayeva ${ }^{3}$, and \\ Bibizhamal Omarova ${ }^{2}$ \\ ${ }^{1}$ Buketov Karaganda State University, Karaganda, Republic of Kazakhstan \\ ${ }^{2}$ Astana Medical University, Nur Sultan, Republic of Kazakhstan \\ ${ }^{3}$ Kazakh Leading Academy of Architecture and Civil Engineering, Almaty, Republic of Kazakhstan
}

\begin{abstract}
This paper examines the environmental problems of the Kyzylorda region associated with the industrial enterprises' activities in the region. The article notes along with economic growth in the mining industry, which is one of the main sectors of the regional economy, the level of pollution in the surrounding ecosystem is increasing. On the one hand, the authors are convinced the growth of the economic potential in the mining industry, space activities and the transition to market mechanisms for the economy development have generated a major growth in the potential of the region turning it into one of the largest developed regions of the Republic of Kazakhstan. On the other hand, an increase in industrial production without taking into account the ecological characteristics of the region with an increase in deformations of sectoral proportions and socioeconomic structure, anthropogenic impact on the environment gave rise to a crisis in the regional ecology. According to the authors, reducing the harmful impact of the Baikonur complex on the environment, preserving the Aral ecosystem, competently using the historical experience of irrigated agriculture, as well as work in the field of environmental awareness and education of nature users will create a favourable environment for a significant improvement in the environmental situation in the region.
\end{abstract}

\section{Introduction}

The change in the eco-cultural space of Kazakhstan began long before the present. This was facilitated by various factors, primarily, by political and social processes that took place in the Kazakh open spaces in the pre-Soviet and Soviet periods [1]. Modern Kazakhstan, which has developed industrial sectors, is faced with environmental problems both regionally and by sector $[2,3]$. This paper will focus on the environmental situation in one of the largest regions of Kazakhstan, the Kyzylorda region.

\footnotetext{
*Corresponding author: mazhitova_69@mail.ru
} 
The economy of the Kyzylorda region is based on industry. It employs more than a quarter of the region's working population and creates about $47.5 \%$ of the region's gross regional product. The mining industry has the greatest influence on the formation of results in the industry as a whole. Its share in the regional production volume in 2010 was $93.9 \%$. In 2010 , the mining industry produced goods for 727.1 billion tenge, which is $1.1 \%$ lower than in the same period in 2009. Crude oil production amounted to 11.0 million tons or $98.1 \%$ by 2009 . The decrease in the volume of mining industry production was due to the decline in oil production, as well as due to the global financial crisis. The Kyzylorda region possesses significant resources that make up the potential of its unique competitive advantages. The reserves of natural resources are represented by rich deposits of iron and polymetallic ores, uranium, oil, sodium chloride, limestone, quartz sands. 125 subsoil users operate in the region, eight of which are enterprises with foreign participation engaged in the production of uranium and oil. In this regard, the main factors contributing to the industrial development of the region are rich mineral resources, its own energy carriers and a developed transport infrastructure. First of all, these are rich hydrocarbon reserves. In the South Turgai trough, the approved reserves amount to over 350 million tons of oil and over 100 billion cubic meters of gas. Preliminary exploration of the Aral Sea basin already predicts 75 million tons of oil and more than 2.3 trillion cubic meters of gas. The potential value of recoverable hydrocarbon reserves in the region is estimated at 130.8 billion US dollars, including oil -72.5 , gas -50.4 , condensate -7.9 billion US dollars. The region contains $65 \%$ - vanadium, $15.1 \%$ - zinc, $13.7 \%$ - uranium, $9.6 \%$ - lead, $4.7 \%$ - oil, gas and condensate, $3.4 \%$ - groundwater from their general Kazakhstan stocks. In addition, useful non-metallic minerals are widespread, i.e., brick loams, expanded clay raw materials, sand and gravel material, quartz sands and sands for building materials, building stones, limestones for the production of lime, table salt. Thus, the potential recoverable value of balance and forecast reserves for the main types of solid minerals gives rise to optimistic forecasts for the socio-economic development of the region and amounts to 26.7 billion US dollars [4].

\section{Materials and Methods}

The study is based on the general research principles of historicism and objectivity. Applying these methods in the research enables to consider scientific knowledge as an integral system in which each previous approach indirectly or directly influenced the next one. All this together made it possible to compile a systematic series of scientific and theoretical calculations on the given issue. The views of authors are discussed regardless of ethnocultural preferences and political inclinations, which necessitates a thorough comparison of facts and phenomena in aggregate, that is, a comprehensive study of the problem.

In addition, a systematic approach, which takes into account both the features of the research objects themselves and the factors that determine these features, is used in the paper. Such approaches allow to identify not only gaps in the studied subject, but also some particular aspects of the problem that might not have come to the scholars' attention for one reason or another. In general, this gives the opportunity to objectively compare these aspects and, on their basis, determine the prospects for further research. 


\section{Discussion of the results}

\subsection{Problem statement}

The productive forces development of the Kyzylorda region has fully corresponded to the general trends of the country's economic development, being implemented for a long time without taking into account regional ecological characteristics coupled with an increase in deformations of sectoral proportions and socio-economic structure. All this has led to a serious aggravation of the ecological situation not only in industrial centers, but throughout the entire region giving rise to a whole range of environmental problems. Almost no town in the Kyzylorda region at the end of the twentieth century was not provided with drinking water of the required quality. Environmental pollution has affected the quality of food. The morbidity and mortality of the population increased, especially in childhood. The existing industrial structure in the Kyzylorda region became the main reason for a fairly wide range of environmental problems, the nature of which, in turn, was largely due to the activities of a particular production complex, the degree of their impact on the quality of atmospheric air, surface and ground waters, the state of soils, forests and other natural spheres. In this regard, it has become revealing that at the end of the twentieth century almost all industrial centers in the Kyzylorda region were included into the category of districts with an alarming and difficult ecological situation. One of the largest environmental challenges of the planet is the Aral Sea problem, which has become extremely acute these days. The socio-economic and environmental situation in the region required a legislative decision and legal regulation of social protection measures for the local population. All districts of the Kyzylorda region and the city of Kyzylorda are declared an ecological disaster zone [5, p. 76]. The Baikonur cosmodrome is located in the Karmaksha district of the Kyzylorda region, which is the first and largest in the world. It occupies an area of $6717 \mathrm{~km}^{2}$ being in operation since 1957. During this time, more than 2000 ballistic and space missiles have been launched. As of 2012, Baikonur retains the leading place in the world in terms of the number of launches, i.e., according to official data from this place 21 launch vehicles were launched in a year; the second place is occupied by the Canaveral Cosmodrome (USA) with 10 launches per year. The legacy of the long-term functioning of the Baikonur cosmodrome has raised a number of global environmental problems for Kazakhstan. The lack of knowledge of these problems in terms of space activities is due to the fact that, until now, all information related to RSA (rocket and space activities) has been and still remains secret. The Baikonur cosmodrome after the collapse of the USSR came under the jurisdiction of Kazakhstan. In accordance with the agreement signed by the Presidents of Kazakhstan and Russia on March 28, 1994, and the lease agreement on December 10, 1994, "Baikonur" from August 1, 1995 was leased to Russia for 20 years [6]. The main ecological threat to the environment is posed by liquid rocket fuels, i.e., unsymmetrical dimethylhydrazine (UDMH, heptyl), which is a highly toxic substance of the $1^{\text {st }}$ hazard class. The World Health Organization has included UDMH on the list of highly hazardous chemical compounds. The danger of getting UDMH into the environment is determined by its high volatility, unlimited solubility in water, the ability to migrate and accumulate. Its traces are found in the soil tens of years after the spill. Heptyl has a general toxic and irritating effect on the human body. It can enter the body through the respiratory system, skin, gastrointestinal tract. In the body, heptyl is distributed evenly, affecting the liver, central nervous, cardiovascular and hematopoietic systems. Its characteristic properties are that it is volatile, it dissolves in water in any ratio, it is capable of accumulation in the body, it easily oxidizes, while forming more dangerous compounds. These include nitrosodimethylamine, which is a yellow liquid, is partially soluble in water and in many other organic solvents. It is 10 times more toxic than heptyl itself. Nitrosodimethylamine is 
dangerous to humans at any intake into the body, it disrupts the activity of many organs and systems. Nitrogen tetroxide (or dinitrogen tetroxide - DT), which is a volatile yellow or red liquid with a pungent odor, is used as an oxidizing agent in rocket engines. It reacts violently with many organic solvents being highly soluble in water. DT is a substance of the $1^{\text {st }}$ hazard class. When inhaled on the human body, the activity of the respiratory system and the cardiovascular system is disturbed primarily. The long-term consequences of acute and chronic DT poisoning can be the development of chronic bronchitis and pulmonary sclerosis. The main disadvantages of UDMH (heptyl) + DT include toxicity, carcinogenicity, the likelihood of an explosion in the presence of an oxidizing agent, high cost in comparison with kerosene [7, p. 54]. Separating parts of launch vehicles (SPLV) with highly toxic rocket fuel that have not burned out to the end are falling on the lands of the Kyzylorda region and Kazakhstan. The poison is partially spilled on the ground (when the first stage of missiles falls, it spills from 1735 to $1957 \mathrm{~kg}$ of heptyl) and it is partially sprayed. In recent years, more frequent accidents of "Proton" space rockets (05.07.1999 Karaganda region, Karkaralinsky region, 27.10.1999 - Karaganda region, Zhanaarkinsky region, 27.07.2006 - Kyzylorda region, Karmakshy region, 06.09. 2007 - Karaganda region, Ulytau region, 02.07.2013 - Kyzylorda region, Karmakshy region) further worsened the ecological situation in the region, polluting the air, soil, flora and underground water sources with heptyl. At the site of the accidental fall of the ILV RS on July 20-27, 2006, the concentration of the toxic substance exceeded the maximum permissible norm by an average of 1000 times [8, p. 120]. Despite a large number of adopted international, multilateral, bilateral conventions, protocols, agreements, treaties in the field of environmental protection and natural resources in the conditions of operation and lease of the Baikonur cosmodrome, the damage caused by space objects does not decrease.

\subsection{Environmental crisis in the atmosphere}

In addition, the main sources of atmospheric pollution in the Kyzylorda region are oil and gas enterprises, heat power engineering, construction and vehicles. According to the Committee on Statistics, in 2018 in the Kyzylorda region, 1,412 enterprises emitted pollutants into the air (in 2017 - by 1,258 enterprises). Anthropogenic sources, which provide the bulk of pollutants in the region, form four groups such as oil and gas production enterprises, i.e., PetroKazakhstan Kumkol Resources JSC, Turgai Petroleum JSC, KazGerMunai JV LLP, KuatAmlonMunai JV LLP, etc.; enterprises for the production of heat and electricity, i.e., Kyzylorda Heat and Power Center SUC, Baikonurenergo SUE EPA, etc.; motor transport, i.e., Keleshek LLP, Kyran LLP, Central Asian Transport LLP, TransAsiaConstraction LLP, SKK-Shieli LLP, SayatTransService LLP, etc.; enterprises engaged in road construction, i.e., Dorstroy LLP, Management of highways LLP, Kyzylorda Zholdary LLP, Kyran LLP, etc. All of the above enterprises emit pollution into the atmosphere in the form of sulfur dioxide, nitrogen dioxide, particulate matter and carbon monoxide, etc. In the Kyzylorda region, the total volume of emissions of pollutants into the air amounted to 26.0 thousand tons (in $2017-27.5$ thousand tons). In 2018, there is a slight decrease in total emissions compared to 2017.

Table 1 provides information on the emissions of the main pollutants into the air [9]. 
Table 1. Volumes of the main pollutant emissions into the air.

\begin{tabular}{|c|c|c|}
\hline \multirow{2}{*}{ Name of pollutants } & \multicolumn{2}{|c|}{ Emission volume } \\
\cline { 2 - 3 } & 2017 & 2018 \\
\hline Sulfur Anhydride & 2.27 & 2.3 \\
\hline Nitrogen dioxide & 3.6 & 4 \\
\hline Solid particles & 4.51 & 4.2 \\
\hline Carbon monoxide & 10.2 & 9.9 \\
\hline
\end{tabular}

In 2018, accidental emissions were recorded. Table 2. presents data on accidental emissions and emissions as a result of gas combustion [10].

Table 2. The volume of accidental emissions and emissions from gas combustion.

\begin{tabular}{|c|c|c|}
\hline Contamination information & 2017 & 2018 \\
\hline Emissions from gas combustion, thousand tons & 1.9 & 2.42 \\
\hline The volume of emergency emissions, thousand tons & 0.0003 & 0.414 \\
\hline
\end{tabular}

On January 29, 2018, in Kyzylorda, an accident occurred on the gas pipeline AGDS-2Gorod: rupture of the welded joint of pipes of an underground gas pipeline of high (R-0.6 $\mathrm{MPa}$ ) pressure. The volume of accidental emissions amounted to 0.0862 thousand tons. The Department of Ecology in the Kyzylorda region during an unscheduled inspection on the $4.7 \mathrm{~km}$ section of the Sarybulak-Arysoy oil pipeline revealed soil contamination with an oil slick on an area of $25 \mathrm{~m}^{2}$. A similar impulse occurred here at the end of 2017 . On the basis of paragraph 2 of Art. 337, art. No. 351, 327 of the Code of Administrative Offenses of the Republic of Kazakhstan, an administrative penalty and a fine were imposed on JSC "CNPC AyDanMunay" (ADNM).

Thus, at present under the influence of industrial activity in the Kyzylorda region, hundreds of chemical pollutants are simultaneously present in the atmospheric air, which are in complex interactions that enhance or neutralize their influence.

\subsection{Ecology of water resources}

The huge volumes of discharged water led to special requirements for treatment facilities, the effluents from which were directly discharged into water bodies. However, many urban wastewater treatment plants have been operating with significant overload in recent years. The main part of the polluted wastewater passing through them was recognized by the inspecting authorities as insufficiently treated, i.e. not meeting the quality of water. This circumstance has caused the need to assess the sanitary state of water bodies in the region and predict the water use of the population, including organizing strict control over the content of chemicals present in water due to industrial, agricultural and domestic pollution. Under the influence of intense pressure from industry, utilities and agriculture, small rivers and lakes were in an unfavorable state, i.e., the quantity reduced, the water content decreased, the regime worsened, the water quality dropped, the flow of water and sediments changed, which led to shallowing and even drying out. The main waterway of the Kyzylorda region is the Syrdarya river with a length of $1280 \mathrm{~km}$ across the region. The river is formed from the confluence of the Naryn and Karadarya rivers, small tributaries of the Fergana Valley, the middle course and tributaries of the Akhangaran, Chirchik, Keles, Kurukkeles and Arys. The total area of the Syrdarya basin is 444 thousand $\mathrm{km}^{2}$. Of these, 250 thousand $\mathrm{km}^{2}$ (or $56.6 \%$ ) are located on the territory of the Republic of Kazakhstan, which are controlled by the Aral-Syrdarya Basin Inspection for the regulation of the use and protection of water resources. Two regions of the republic, South Kazakhstan and Kyzylorda, are almost entirely located in the Syrdarya basin (with the exception of the Suzak region of the South Kazakhstan region) included in four water management regions, 
i.e., the middle reaches - the Golodnaya steppe of the Republic of Kazakhstan with an area of about two thousand $\mathrm{km}^{2}$, Chirchik-Angren-Keles irrigation region -12 thousand $\mathrm{km}^{2}$, Arys-Turkestan -28 thousand $\mathrm{km}^{2}$ and the lower reaches -208 thousand $\mathrm{km}^{2}$. On the territory of the Kyzylorda region, there is a part of the Aral Sea, the basin of which is a closed-off region, consisting of two independent basins of the Amu Darya and Syrdarya. The entire river runoff of the Aral region is formed due to seasonal melting of snow and glaciers. Since the 1960s, the sea level (and the volume of water in it) began to decline rapidly due to the withdrawal of water for irrigation from the main rivers feeding the Aral the Amu Darya and Syrdarya as well. In 1989 the sea split into two isolated reservoirs, i.e., the North (Small) and South (Big) Aral Sea. Before the shallowing began, the Aral Sea was the fourth largest lake in the world. In 2018, Kazhydromet RSE carried out a chemical analysis of drinking water in the city of Kyzylorda. Sampling was carried out at the city water intake (Tasbuget settlement, Shukurov street) tap water (before entering the distribution network), from an open reservoir (from the Syrdarya river to purification and filtration), underground sources - deep wells (well - water intake 100-120 m). In the districts of the region, water samples were taken at regional water intakes from an open reservoir (from the Syrdarya river before purification and filtration), underground sources deep wells, a water supply network and decentralized water supply sources (wells, pumping columns). The main parameters for determining the contamination of drinking water are color, turbidity, hardness, sulfates, dry residue, magnesium. In open water bodies, color 2.3 (maximum permissible coefficient - MPC), turbidity - 1.1 MPC, dry residue -1.3 MPC. In deep wells: dry residue - 1.0 MPC. In the water supply network, an excess of the dry residue was observed - 1.1 MPC. In open water bodies, turbidity is 1.0-1.1 MPC; chromaticity 1.0-2.4 MPC; dry residue 1.1-1.3 MPC; hardness 1.0-1.1 MPC; magnesium 1.1 MPC. In decentralized sources, color 1.0-1.2 MPC, turbidity 1.0-1.1 MPC, sulfates 1.0-1.2 MPC, dry residue 1.0-1.1 MPC; hardness - 1.1 MPC, magnesium 1.0-1.3 MPC. In 2018 , compared to 2017 , there were no significant changes in the quality of drinking water. According to the Kazhydromet RSE, observations of surface water pollution in the Kyzylorda region were carried out at two water bodies, i.e., the Syrdarya river and the Aral Sea. In the Syrdarya, the water temperature was noted within the range of $0-26.8{ }^{\circ} \mathrm{C}$, the average $\mathrm{pH}$ value $=7.99$, the concentration of oxygen dissolved in water averaged $5.40 \mathrm{mg}$ $/ \mathrm{dm}^{3}$, biochemical oxygen demand5 (BOD5) averaged $=1.21 \mathrm{mg} / \mathrm{dm}^{3}$. MPC excess was recorded for substances from the group of heavy metals (copper - 2-2.4 MPC), main ions (sulfates - 4.6 MPC), biogenic substances (total iron - 1.5 MPC). In the Aral Sea, the water temperature is $0-26.4{ }^{\circ} \mathrm{C}$, the average $\mathrm{pH}$ value $=7.85$, the concentration of oxygen dissolved in the water was $5.26 \mathrm{mg} / \mathrm{dm}^{3}$, BOD5 $-1.17 \mathrm{mg} / \mathrm{dm}^{3}$. MPC excess of was recorded for substances from the group of heavy metals (copper2 $+2.3 \mathrm{MPC}$ ), main ions (sulfates - 4.6 MPC, magnesium - 1.1 MPC), biogenic substances (total iron - 1.3 MPC). The water quality of the Syrdarya river and the Aral Sea in the Kyzylorda region is assessed as "moderate level of pollution". Compared to 2017, the water quality in the basins of the Syrdarya River and the Aral Sea has not changed significantly. In the Kyzylorda region, in the period from 01-03 March 2018, four cases of EHP (extremely high pollution) were found on the Syrdarya. Table 3. presents data on the actual volumes of discharges [11].

Table 3. Actual volumes of discharges. 


\begin{tabular}{|c|l|c|c|}
\hline \multicolumn{2}{|c|}{ Actual volumes of discharges } & 2017 & 2018 \\
\hline \multirow{2}{*}{\begin{tabular}{c} 
Industrial discharges \\
\cline { 2 - 4 }
\end{tabular}} & Water disposal volume, thousand $\mathrm{m}^{3}$ & 343.698 & 592.013 \\
\cline { 2 - 4 } & Volume of pollutants, thousand tons & 0.02 & 0.03 \\
\hline \multirow{2}{*}{$\begin{array}{c}\text { Domestic waste water } \\
\text { Emergency and unauthorized } \\
\text { discharges }\end{array}$} & Water disposal volume, thousand $\mathrm{m}^{3}$ & 13257.6 & 13824.252 \\
\cline { 2 - 4 } & Volume of pollutants, thousand tons & 12.09 & 12.241 \\
\cline { 2 - 4 } & Water disposal volume, thousand $\mathrm{m}^{3}$ & 0.0 & 0,0 \\
\hline \multirow{2}{*}{$\begin{array}{c}\text { Discharges to surface water } \\
\text { Tolume of pollutants, thousand tons }\end{array}$} & 0.0 & 0,0 \\
\hline \multirow{2}{*}{$\begin{array}{c}\text { Total (all of the above } \\
\text { discharges) }\end{array}$} & Water disposal volume, thousand $\mathrm{m}^{3}$ & 13601.3 & 13642,013 \\
\cline { 2 - 4 } & Volume of pollutants, thousand tons & 13.01 & 0,03 \\
\cline { 2 - 4 } & Water disposal volume, thousand $\mathrm{m}^{3}$ & 27202.55 & 28058.278 \\
\hline & Volume of pollutants, thousand tons & 25.121 & 0.06 \\
\hline
\end{tabular}

The increase in the total volume of domestic wastewater discharges in comparison with 2017 amounted to 556.7 thousand $\mathrm{m}^{3}$ associated with an increase in discharges by oil producing enterprises, as well as an increase in the population of Kyzylorda. In the Kyzylorda region, industrial discharge (conditionally clean) into the Syrdarya river is carried out by the State Unitary Enterprise PEO "Baikonurenergo" (Baikonur). In 2018, the volume of industrial discharge compared to 2017 increased by 248.3 thousand $\mathrm{m}^{3}$. This is due to the increased use of water for boilers and heating systems during the heated period of the year. The main share of domestic wastewater falls on the treatment facilities of the State Unitary Enterprise PO Gorvodokanal in Baikonur and large oil companies: JSC PetroKazakhstanKumkolResources, JSC Turgai Petroleum, LLP Joint Venture KazGerMunai, which account for $90 \%$ of the total volume of discharges. Emergency and unauthorized discharges - none. In accordance with the plan for the preservation, accumulation and distribution of flood waters and restoration, arrangement of watering structures (wells) for watering livestock on distant pastures (approved by a meeting chaired by the Prime Minister of the Republic of Kazakhstan No. 11-5 / 07-591 dated 05.06.2017.), it is planned to implement 6 projects in the region with a volume of flood water accumulation of 3 billion $\mathrm{m}^{3}$. Among them are the Kumisketken reservoir with a water storage volume of 600 million $\mathrm{m}^{3}$ and a reservoir on the Karaozek channel with a water storage volume of 1.5 billion $\mathrm{m}^{3}$. The main function of the Kumisketken reservoir is to regulate water in the region by accumulating water during the highwater period on the Syrdarya river for irrigation of crops during the growing season. In addition, the Karaozek reservoir will be used to fill lake systems and watering hay and pasture lands for livestock farming. The work on cleaning and repairing water facilities is being carried stepwise in order to provide the settlements with irrigation water. In 2018, water management works were carried out on 6 canals (the Basykara canal in the Akirek aul district of the Aral region, the Balgabay, Beketay, Stan canals in the Bogen aul district, the Beszharma canal in the Raiym aul district, the Balazharma canal in the aul districts of Irkol and Torebay bi of the Karmakshy region), three pumping equipment was purchased for the aul districts of Birkazan and Talsuat in Kyzylorda and the aul district of Keiden in the Zhanakorgan region. The implementation of the project "Regulation of the Syrdarya river and the Preservation of the Northern Part of the Aral Sea" (RSRNAS) has begun in order to restore the ecological disaster zone of the Aral Sea. The second phase of regulation of the Syrdarya river and the Northern Aral Sea (RSRNAS) is part of a large international program for the environmental remediation of the Aral Sea basin prepared by the World Bank in cooperation with the United Nations Environment Program. The RSRNAS-2 project is a continuation of the implemented RSRNAS-1 project and is aimed at solving the following 
tasks: continuation of the ecological revival of the Aral Sea region; improving the efficiency of water use in the lower reaches of the Syrdarya river; improving organizational capacity for water resources management (WRM) at local, national and interstate transboundary levels. The project area includes the Kazakh part of the Syrdarya river basin and the Northern Aral Sea (NAS). The Government of the Republic of Kazakhstan made a decision to start implementation of four out of six components of the RSRNAS-2 project necessary to ensure the safety of the population at the expense of the republican budget. After their implementation, the sea is expected to approach Aralsk at a distance of one kilometer, which will increase the volume of fish catch and open new jobs $[12,13]$.

\section{Conclusion}

An analysis of the industrial development in the Kyzylorda region in the context of environmental problems allows to identify the typical regional reasons for the critical state of the environment that emerged at the beginning of the $21^{\text {st }}$ century. This is a technocratic approach to solving environmental problems aimed not at radical socio-economic transformations, but calculated on quantitative, superficial changes, which, in particular, only increase the depersonalization of natural resources ownership. Irresponsibility and lack of control of the relevant ministries, departments, regional and local self-government bodies, the activities of which are often aimed not for the good, but to the detriment of the environment as well as one-sided consumer approach to please momentary economic interests, the consequence of which is the absence of a promising strategic beginning in environmental protection, low level ecological culture, education and consciousness of the population.

Modern regional environmental problems resulting from these shortcomings require a significant intensification of the entire environmental management system as a whole, and especially the sphere of land and forest management as well as the competent use of mineral deposits. A complex combination of natural and anthropogenic impacts, among which the most significant is industrial impact, serves as the basis for predictions regarding further aggravation of environmental problems. The task of ecological rehabilitation of this region is multifaceted, but quite feasible.

In this regard, the following promising directions for optimizing the state of the environment of the Kyzylorda region seem to be the most important: 1. Reducing the harmful impact of the Baikonur complex on the environment of the Kyzylorda region, areas of fall of the separating parts of the first stages of launch vehicles (SPLV). 2. Preservation of the ecosystem of the Aral Sea through the development of a scientifically grounded and economical scheme of water consumption from the Amu Darya and Syrdarya rivers. It is necessary that the scheme of optimal water consumption be developed by a commission with international status, so that it includes not only independent scientific forces, but also representatives of the authorities who have the right to approve the flow of water at the sites as a strict law. 3. Using the centuries-old experience of irrigated agriculture, while it is necessary to reconstruct the irrigation and drainage-collector network very carefully taking into account the structure of the soil cover and preserving the principles of contouring irrigated agriculture. Refusal from cotton monoculture farming, restoration of crops traditionally cultivated in oases, reduction of water intake per unit of irrigated area, improvement of irrigation technique and regime, exclusion of irrigation water discharge into the drainage and collector network - all this will allow to reduce the volume of drainage flows from irrigated lands; 4. Particular attention should be paid to the greening of the nature users' consciousness and the formation of appropriate public awareness, since the changes in the world necessitate the formation of a holistic humanistic worldview in relation to nature, in which universal human values will receive priority. 


\section{References}

1. Zh. Mazhitova Place and Role of the Biy Council and People's Assembly in the Traditional Kazakh Society of the XVIII-XIX Centuries (Following the Data of the Pre-Revolutionary Russian Historiography) Asian Social Science, 10, No. 20, 129-136 (2014) https://doi.org/ 10.5539/ass.v10n20p129

2. T. Alimbaev, Zh. Mazhitova, B. Omarova, B. Kamzaev, K. Atanakova. Ecological problems of modern central Kazakhstan: challenges and possible solutions E3S Web of Conferences, 157, 1-8 (2020)

3. T. Alimbaev, Zh. Mazhitova, Ch. Beksultanova, N. Tentigul kyzy. Activities of mining and metallurgical industry enterprises of the Republic of Kazakhstan: environmental problems and possible solutions E3S Web of Conferences, 175, 1-9 (2020)

4. Program for the development of the territory of the Kyzylorda region for 2016-2020 Kyzylorda, 56 (2015)

5. Regional program for environmental protection of the Kyzylorda region for 2009-2011 Kyzylorda, 76 (2009)

6. L. V. Pushkareva, O. A. Galochkina, O. L. Bezgacheva, Espacios 40(4), 22 (2019)

7. R. Khaliullin. Strong poisonous substances. Hydrazine and its derivatives Moscow: Russian University of Chemical Technology, 54 (1998)

8. M. Cherkasova. Socio-ecological consequences of rocket and space activities Moscow: CNEP-SoES, 120 (2000)

9. National report on the state of the environment and the use of natural resources in the Republic of Kazakhstan for 2018 (Astana, 2019)

10. National report on the state of the environment and on the use of natural resources in the Republic of Kazakhstan for 2018 (Astana, 2019)

11. National report on the state of the environment and the use of natural resources in the Republic of Kazakhstan for 2018 (Astana, 2019)

12. Regulation of the Syr Darya river bed and preservation of the Northern part of the Aral Sea "SRNAS" Collection of documents Almaty, 54 (2017)

13. O. Grigorieva, Constitutional basis for international cooperation of the Union of Soviet Socialist Republics Giornale di Storia Costituzionale 33 (1), pp 109-120 (2017) 